\title{
EFFECTS OF DUST EXPOSURE ON LUNG FUNCTION CAPACITY OF TILE INDUSTRY WORKERS IN SUKOHARJO, CENTRAL JAVA
}

\author{
Aurina Firda Kusuma Wardani, Sunardi, Nine Elissa Maharani \\ Faculty of Public Health, Universitas Veteran Bangun Nusantara
}

\begin{abstract}
Background: Occupational lung disease is a major concern and it has been listed as one of the priority problems in occupational health. Airborne dusts are being potentially harmful for workers in occupational environment. Exposure to respirable dust is the most important concern in textile workers for the widespread of occupational lung diseases. The purpose of this study was to examine effects of dust exposure on lung function capacity of tile industry workers.

Subjects and Method: This was an analytic observational study with a cross sectional design. The study was carried out at roof tiles industrial village in Mojolaban, Sukoharjo, Central Java, Indonesia, in August 2019. A sample of 32 roof tiles workers was selected by purposive sampling. The dependent variable was lung functional capacity. The independent variable was dust exposure. Dust exposure was measured using personal dust sampler. Lung functional capacity was measured by spirometry. The data were analyzed by Chi square.

Results: Mean of dust exposure was $2.21 \mathrm{mg} / \mathrm{m}^{3}$. Dust exposure increased the risk of poor lungs functional capacity in roof tiles workers and it was statistically significant $(\mathrm{OR}=5.80 ; 95 \% \mathrm{CI}=2.61$ to $12.87 ; \mathrm{p}=0.011)$.

Conclusion: Dust exposure increases the risk of poor lungs functional capacity in roof tiles workers.
\end{abstract}

Keywords: dust exposure, lung functional capacity, roof tiles workers

\section{Correspondence:}

Aurina Firda Kusuma Wardani. Faculty of Public Health, Universitas Veteran Bangun Nusantara. Jl. Letjend Sujono Humardani 1, Sukoharjo, Central Java. Email: firdakw@gmail.com. Mobile: 082135012135. 